\title{
Transfer of Sejongia antarctica, Sejongia jeonii and Sejongia marina to the genus Chryseobacterium as Chryseobacterium antarcticum comb. nov., Chryseobacterium jeonii comb. nov. and Chryseobacterium marinum comb. nov.
}

Correspondence

Peter Kämpfer

peter.kaempfer@

umwelt.uni-giessen.de

\author{
Peter Kämpfer, ${ }^{1}$ Nicole Lodders, ${ }^{1}$ Mario Vaneechoutte ${ }^{2}$ \\ and Georges Wauters ${ }^{3}$
}

\author{
${ }^{1}$ Institut für Angewandte Mikrobiologie, Justus-Liebig-Universität Giessen, Germany \\ ${ }^{2}$ Laboratory Bacteriology Research, Department of Clinical Chemistry, Microbiology and \\ Immunology, University of Ghent, Ghent, Belgium \\ ${ }^{3}$ Microbiology Unit, Faculty of Medicine, University of Louvain, Brussels, Belgium
}

The genus Sejongia was described in 2005, with the two species Sejongia antarctica and Sejongia jeonii, mainly on the basis of $16 \mathrm{~S}$ rRNA gene sequence analysis. At that time, these organisms formed a quite separate branch in a 16S rRNA gene sequence-based tree, but, in subsequent studies, it became obvious that the species $S$. antarctica and $S$. jeonii and a third species, Sejongia marina, were most closely related ( $>95.0 \%$ similarity) to some Chryseobacterium species (e.g. Chryseobacterium hominis, C. formosense and C. haifense). In addition, there is no evidence for clear phenotypic (i.e. chemotaxonomic) differences between these organisms that justifies their assignment to different genera. For these reasons, a proposal is made to transfer these species to the genus Chryseobacterium as Chryseobacterium antarcticum comb. nov. (type strain AT1013 ${ }^{\top}=\mathrm{JCM} 12381^{\top}=\mathrm{IMSNU} 14040^{\top}=\mathrm{KCTC} 12225^{\top}$ ), Chryseobacterium jeonii comb. nov. (type strain AT1047 ${ }^{\top}=\mathrm{JCM} 12382^{\top}=$ IMSNU $14049^{\top}$ $=\mathrm{KCTC}_{12226^{\top}}$ ) and Chryseobacterium marinum comb. nov. (type strain IMCC3228 ${ }^{\top}=\mathrm{KCCM}$ $42689^{\top}=$ NBRC $103143^{\top}$ ) on the basis of $16 \mathrm{~S}$ rRNA gene sequence data and published phenotypic data.
The genus Chryseobacterium was proposed by Vandamme et al. (1994) in the course of the subdivision of the genus Flavobacterium, which at that time contained a rather heterogeneous group of yellow-pigmented, Gram-negative organisms. At that time, the new genus Chryseobacterium contained the six species Chryseobacterium balustinum, $C$. gleum, C. indologenes, C. indoltheticum, C. meningosepticum and C. scophthalmum. These species were similar in many respects. They share many classical phenotypic features: they all contain menaquinone $6(\mathrm{MK}-6)$ as their major respiratory quinone and they have similar fatty acid profiles, which are characterized by large amounts of iso$15: 0$, iso- $17: 1 \omega 9 c$, iso- $17: 03-\mathrm{OH}$ and summed feature 4 (iso-15:0 2-OH and/or $16: 1 \omega 7 c$ ). Within this group, $C$. meningosepticum revealed the most aberrant fatty acid profile and was subsequently transferred to the new genus Elizabethkingia (Kim et al., 2005b). Between 1994 and 2008, the number of Chryseobacterium species increased significantly, to 37 species with validly published names (de Beer et al., 2005; Gallego et al., 2006; Herzog et al., 2008;
Kämpfer et al., 2003, 2009; Kim et al., 2005a, 2008; Li et al., 2003; Park et al., 2006; Quan et al., 2007; Shen et al., 2005; Shimomura et al., 2005; Tai et al., 2006; Vaneechoutte et al., 2007; Weon et al., 2006; Young et al., 2005). This increase in the number of species was accompanied by the proposal of two novel genera, Kaistella (Kim et al., 2004) and Sejongia (Yi et al., 2005), that share many features of Chryseobacterium species. The reclassification of the sole species of the genus Kaistella in the genus Chryseobacterium is proposed elsewhere (Kämpfer et al., 2009).

Recently, several Chryseobacterium species, i.e. Chryseobacterium haifense (Hantsis-Zacharov \& Halpern, 2007), C. hominis (Vaneechoutte et al., 2007) and 'C. anthropi' (Kämpfer et al., 2009), amongst others, have been described with high 16S rRNA gene sequence similarities to the species of the genus Sejongia. In comparisons of the $16 \mathrm{~S}$ rRNA gene sequences of type strains, $C$. haifense showed similarities of $95.3 \%$ to Sejongia antarctica, $95.8 \%$ to Sejongia jeonii and $95.0 \%$ to Sejongia marina, C. hominis showed similarities of $95.1 \%$ to S. antarctica, $96.5 \%$ to $S$. 
jeonii and $95.6 \%$ to $S$. marina and 'C. anthropi' showed similarities of $95.3 \%$ to $S$. antarctica, $95.9 \%$ to $S$. jeonii and $94.8 \%$ to $S$. marina. $16 \mathrm{~S}$ rRNA gene sequence similarities of the type strain of $C$. formosense (Young et al., 2005) were $95.7 \%$ to S. antarctica, $96.3 \%$ to $S$. jeonii and $95.9 \%$ to $S$. marina. Similarities were calculated using the ARB software package (version December 2007; Ludwig et al., 2004) and the corresponding SILVA SSURef 95 database (release July 2008; Pruesse et al., 2007).

The 16S rRNA gene sequences for all strains under comparison were analysed as described above. Trees were reconstructed using the maximum-likelihood method with fastDNAml (Olsen et al., 1994) and a 50\% conservation filter (only alignment columns in which the frequency of the most abundant nucleotide is equal to or more than $50 \%$ are included in the calculation). Tree topology was further tested with no conservation filter and with 30 and $40 \%$ conservation filters. No significant differences could be detected between these trees. For tree reconstruction, 90 sequences were included. For better clarity, only a subset of the sequences used for treeing are shown in Fig. 1.

On the basis of these comparisons, the type strains of the three Sejongia species fell clearly in the Chryseobacterium cluster at a depth similar to other Chryseobacterium species groups.

Although respiratory quinones have low resolution within this group, the presence of MK-6 supports affiliation of the Sejongia species to the genus Chryseobacterium, where all species investigated to date have MK-6 as the major quinone.

The fatty acid profiles of all Sejongia species were very similar to those of species of Chryseobacterium, as reported already by Yi et al. (2005). All Sejongia species reveal iso$15: 0$, anteiso-15:1 and iso- $17: 1 \omega 9 c$ as the major fatty acids (Yi et al., 2005; Lee et al., 2007), which is essentially in agreement with the fatty acid patterns of Chryseobacterium species (de Beer et al., 2005; Gallego et al., 2006; Herzog et al., 2008; Kämpfer et al., 2003, 2009; Kim et al., 2005a, 2008; Li et al., 2003; Park et al., 2006; Quan et al., 2007; Shen et al., 2005; Shimomura et al., 2005; Tai et al., 2006; Vaneechoutte et al., 2007; Weon et al., 2006; Young et al., 2005).

In conclusion, the species of Sejongia and Chryseobacterium show a strong congruence in phenotypic characters, in that they all produce MK- 6 as the major menaquinone and the fatty acid profiles are very similar. Only a few differences have been reported with regard to cell morphology and certain physiological tests.

For these reasons, it is proposed to reclassify Sejongia antarctica, Sejongia jeonii and Sejongia marina in the genus Chryseobacterium as the new combinations Chryseobacterium antarcticum comb. nov., Chryseobacterium jeonii comb. nov. and Chryseobacterium marinum comb. nov.

\section{Description of Chryseobacterium antarcticum comb. nov.}

Chryseobacterium antarcticum (ant.arc'ti.cum. L. neut. adj. antarcticum southern, named after Antarctica, the geographical origin of the type strain).

Basonym: Sejongia antarctica Yi et al. 2005.

The description is that of Yi et al. (2005). The type strain is $\mathrm{AT} 1013^{\mathrm{T}}\left(=\mathrm{IMSNU} 14040^{\mathrm{T}}=\mathrm{KCTC} 12225^{\mathrm{T}}=\mathrm{JCM}\right.$ $\left.12381^{\mathrm{T}}\right)$.

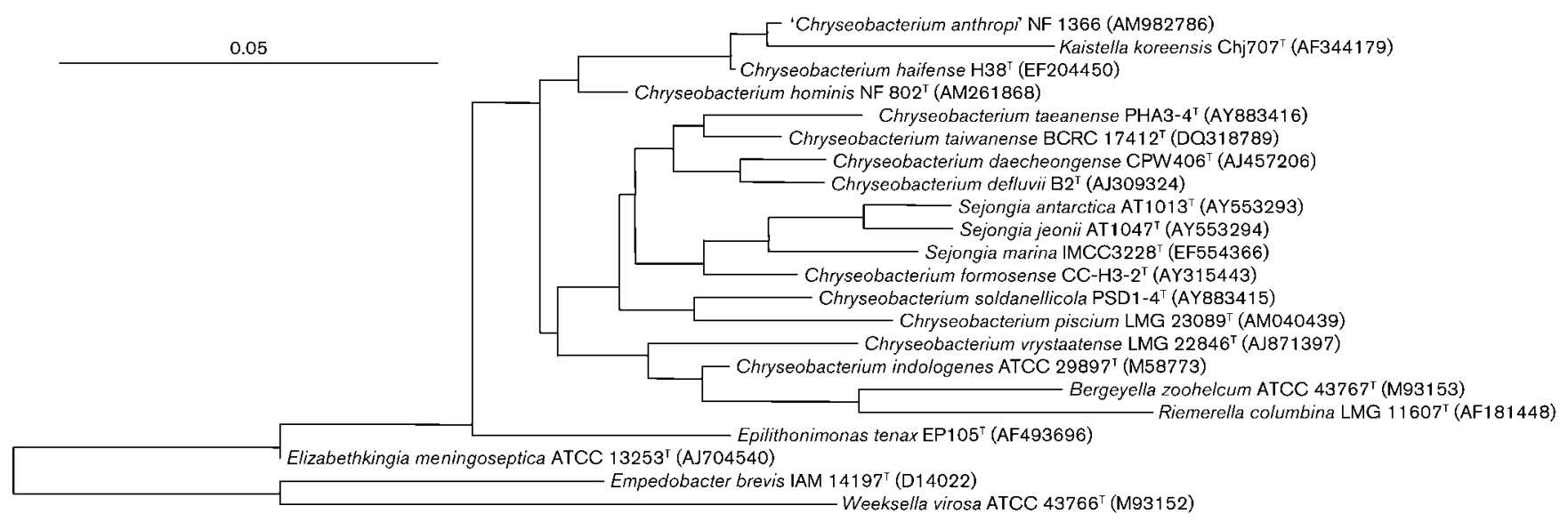

Fig. 1. Phylogenetic analysis based on $16 \mathrm{~S}$ rRNA gene sequences available from the EMBL database (accession numbers in parentheses). The phylogenetic tree was constructed using the ARB software package (version December 2007; Ludwig et al., 2004) and the corresponding SILVA SSURef 95 database (version July 2008; Pruesse et al., 2007). Tree building was performed with 90 sequences using the maximum-likelihood method with fastDNAml (Olsen et al., 1994) and 50\% conservation filter. For better clarity, only a subset of the sequences used for treeing is shown. Bar, 0.05 substitutions per nucleotide position. 


\section{Description of Chryseobacterium jeonii comb. nov.}

Chryseobacterium jeonii (jeo'ni.i. N.L. gen. n. jeonii named in honour of the late Jae Gyu Jeon, who devoted his life to polar research).

Basonym: Sejongia jeonii Yi et al. 2005.

The description is that of Yi et al. (2005). The type strain is AT1047 $^{\mathrm{T}}\left(=\mathrm{IMSNU} 14049^{\mathrm{T}}=\right.$ KCTC $\left.12226^{\mathrm{T}}=\mathrm{JCM} 12382^{\mathrm{T}}\right)$.

\section{Description of Chryseobacterium marinum comb. nov.}

Chryseobacterium marinum (ma.ri'num. L. neut. adj. marinum of the sea, marine).

Basonym: Sejongia marina Lee et al. 2007.

The description is that of Lee et al. (2007). The type strain is $\operatorname{IMCC} 3228^{\mathrm{T}}\left(=\mathrm{KCCM} 42689^{\mathrm{T}}=\mathrm{NBRC} 103143^{\mathrm{T}}\right)$.

\section{References}

de Beer, H., Hugo, C. J., Jooste, P. J., Willems, A., Vancanneyt, M., Coenye, T. \& Vandamme, P. A. (2005). Chryseobacterium vrystaatense sp. nov., isolated from raw chicken in a chicken-processing plant. Int $J$ Syst Evol Microbiol 55, 2149-2153.

Gallego, V., Garcia, M. T. \& Ventosa, A. (2006). Chryseobacterium hispanicum sp. nov., isolated from the drinking water distribution system of Sevilla, Spain. Int J Syst Evol Microbiol 56, 1589-1592.

Hantsis-Zacharov, E. \& Halpern, M. (2007). Chryseobacterium haifense sp. nov., a psychrotolerant bacterium isolated from raw milk. Int J Syst Evol Microbiol 57, 2344-2348.

Herzog, P., Winkler, l., Wolking, D., Kämpfer, P. \& Lipski, A. (2008). Chryseobacterium ureilyticum sp. nov., Chryseobacterium gambrini sp. nov., Chryseobacterium pallidum sp. nov. and Chryseobacterium molle sp. nov., isolated from beer-bottling plants. Int J Syst Evol Microbiol 58, 26-33.

Kämpfer, P., Dreyer, U., Neef, A., Dott, W. \& Busse, H.-J. (2003). Chryseobacterium defluvii sp. nov., isolated from wastewater. Int J Syst Evol Microbiol 53, 93-97.

Kämpfer, P., Vaneechoutte, M., Lodders, N., De Baere, T., Avesani, V., Janssens, M., Busse, H.-J. \& Wauters, G. (2009). Description of Chryseobacterium anthropi sp. nov., to accommodate clinical isolates biochemically similar to Kaistella koreensis and Chryseobacterium haifense, proposal to reclassify Kaistella koreensis as Chryseobacterium koreense comb. nov. and emended description of the genus Chryseobacterium. Int J Syst Evol Microbiol 59(in press). doi:10.1099/ ijs.0.008250-0.

Kim, M. K., Im, W. T., Shin, Y. K., Lim, J. H., Kim, S. H., Lee, B. C., Park, M. Y., Lee, K. Y. \& Lee, S. T. (2004). Kaistella koreensis gen. nov., sp. nov., a novel member of the Chryseobacterium-Bergeyella-Riemerella branch. Int J Syst Evol Microbiol 54, 2319-2324.

Kim, K. K., Bae, H. S., Schumann, P. \& Lee, S. T. (2005a). Chryseobacterium daecheongense sp. nov., isolated from freshwater lake sediment. Int J Syst Evol Microbiol 55, 133-138.

Kim, K. K., Kim, M. K., Lim, J. H., Park, H. Y. \& Lee, S. T. (2005b). Transfer of Chryseobacterium meningosepticum and Chryseobacterium miricola to Elizabethkingia gen. nov. as Elizabethkingia meningoseptica comb. nov. and Elizabethkingia miricola comb. nov. Int J Syst Evol Microbiol 55, 1287-1293.

Kim, K. K., Lee, K. C., Oh, H.-M. \& Lee, J.-S. (2008). Chryseobacterium aquaticum sp. nov., isolated from a water reservoir. Int $J$ Syst Evol Microbiol 58, 533-537.

Lee, K., Lee, H. K., Choi, T.-H. \& Cho, J.-C. (2007). Sejongia marina sp. nov., isolated from Antarctic seawater. Int J Syst Evol Microbiol 57, 2917-2921.

Li, Y., Kawamura, Y., Fujiwara, N., Naka, T., Liu, H., Huang, X., Kobayashi, K. \& Ezaki, T. (2003). Chryseobacterium miricola sp. nov., a novel species isolated from condensation water of space station Mir. Syst Appl Microbiol 26, 523-528.

Ludwig, W., Strunk, O., Westram, R., Richter, L., Meier, H., Yadhukumar, Buchner, A., Lai, T., Steppi, S. \& other authors (2004). ARB: a software environment for sequence data. Nucleic Acids Res 32, 1363-1371.

Olsen, G. J., Matsuda, H., Hagström, R. \& Overbeek, R. (1994). fastDNAml: a tool for construction of phylogenetic trees of DNA sequences using maximum likelihood. Comput Appl Biosci 10, 41-48.

Park, M. S., Jung, S. R., Lee, K. H., Lee, M. S., Do, J. O., Kim, S. B. \& Bae, K. S. (2006). Chryseobacterium soldanellicola sp. nov. and Chryseobacterium taeanense sp. nov., isolated from roots of sand-dune plants. Int J Syst Evol Microbiol 56, 433-438.

Pruesse, E., Quast, C., Knittel, K., Fuchs, B. M., Ludwig, W., Peplies, J. \& Glöckner, F. O. (2007). SILVA: a comprehensive online resource for quality checked and aligned ribosomal RNA sequence data compatible with ARB. Nucleic Acids Res 35, 7188-7196.

Quan, Z.-X., Kim, K. K., Kim, M.-K., Jin, L. \& Lee, S. T. (2007). Chryseobacterium caeni sp. nov., isolated from bioreactor sludge. Int $J$ Syst Evol Microbiol 57, 141-145.

Shen, F. T., Kämpfer, P., Young, C. C., Lai, W. A. \& Arun, A. B. (2005). Chryseobacterium taichungense sp. nov., isolated from contaminated soil. Int J Syst Evol Microbiol 55, 1301-1304.

Shimomura, K., Kaji, S. \& Hiraishi, A. (2005). Chryseobacterium shigense sp. nov., a yellow-pigmented, aerobic bacterium isolated from a lactic acid beverage. Int J Syst Evol Microbiol 55, 1903-1906.

Tai, C. J., Kuo, H. P., Lee, F. L., Chen, H. K., Yokota, A. \& Lo, C. C. (2006). Chryseobacterium taiwanense sp. nov., isolated from soil in Taiwan. Int J Syst Evol Microbiol 56, 1771-1776.

Vandamme, P., Bernardet, J.-F., Segers, P., Kersters, K. \& Holmes, B. (1994). New perspectives in the classification of the flavobacteria: description of Chryseobacterium gen. nov., Bergeyella gen. nov., and Empedobacter nom. rev. Int J Syst Bacteriol 44, 827-831.

Vaneechoutte, M., Kämpfer, P., De Baere, T., Avesani, V., Janssens, M. \& Wauters, G. (2007). Description of Chryseobacterium hominis sp. nov. to accommodate clinical isolates biochemically similar to CDC groups II-h and II-c. Int J Syst Evol Microbiol 57, 2623-2628.

Weon, H. Y., Kim, B. Y., Yoo, S. H., Kwon, S. W., Cho, Y. H., Go, S. J. \& Stackebrandt, E. (2006). Chryseobacterium wanjuense sp. nov., isolated from greenhouse soil in Korea. Int J Syst Evol Microbiol 56, 1501-1504.

Yi, H., Yoon, H. I. \& Chun, J. (2005). Sejongia antarctica gen. nov., sp. nov. and Sejongia jeonii sp. nov., isolated from the Antarctic. Int J Syst Evol Microbiol 55, 409-416.

Young, C. C., Kämpfer, P., Shen, F. T., Lai, W. A. \& Arun, A. B. (2005). Chryseobacterium formosense sp. nov., isolated from the rhizosphere of Lactuca sativa L. (garden lettuce). Int J Syst Evol Microbiol 55, 423426. 